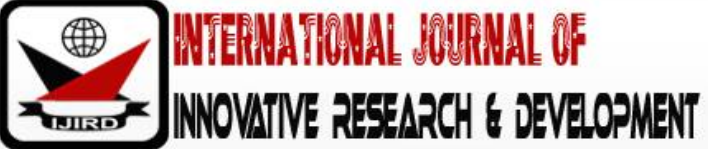

ISSN 2278-0211 (Online)

\section{Curbing the Rising Tide in Social Vices among Nigerian Undergraduates: The Role of Women in Academia}

\author{
Veronica Ibitola MAKINDE \\ Chief Lecturer, Department of Educational Psychology, \\ College of Education, Ikere, Ekiti, Nigeria \\ Oluwabunmi Veronica Kehinde-Dada \\ Lecturer, Department of General Studies, College of Education, Ikere Ekiti, Nigeria \\ Christianah Adekemi Babatunde \\ Lecturer, Department of Educational Psychology, \\ College of Education, Ikere, Ekiti, Nigeria
}

\begin{abstract}
:
This paper examined some common social vices among the students in tertiary institutions and their effects on the sustainability of the nation. Some factors such as corruption, poverty, get rich quick syndrome, poor governance, unemployment which are indicators of high rise in social vices were identified for discussion. Finally, the paper discussed the role of women in academia at curbing the rising tide of social vices in our education system. It was recommended among other things that women in academia should provide mentorship within the school system for quality assurance. Women in academia should partner with their school management team to ensure that school curriculum is geared towards knowledge economy that would result in job and wealth creation. Courses like entrepreneurship studies and moral education should be strengthened to enhance the right attitude. Adequate educational guidance and counselling should be sustained at all levels of education with more women participation as paraprofessionals.
\end{abstract}

Keywords: Education, Social Vices, undergraduates, women in academia

\section{Introduction}

The Federal Government through the National Policy on Education affirmed that Education remained the instrument per - excellence for achieving the national objective. It is a vehicle that drives the human and material resources of any nation as it provides information that propels physical, cognitive, moral, social, emotional, economic and political development. It is also a medium through which the cultural practices, norms and values of good character, honesty, integrity, and respect for constituted authority, hard work and orderliness are inculcated from one generation to the other. John Dewey cited by Wikipedia defines education as the process of facilitating learning, or acquisition of knowledge, skills, values, beliefs, and habits; the process which frequently permits learning to take place under the guidance of educators, or learners educating themselves. Okwori and Ede (2012) also define education as the transmission of relevant knowledge into the learner to enable him to effectively adjust to his environment and live a useful life. Education enables the possessor to live a useful life by contributing to the development of the society.

While stressing the importance of education, Edogun (2015) stated that education helps people work better and create opportunities for sustainable and viable economic growth for the future, gives people critical skills and tools to help them provide for themselves and their children. He went further to state that education is required for an individual to adapt with ever changing world where new technologies keep coming up. He also stressed that educated people tend to know better about the preventive methods which protect them from avoidable diseases while illiterate and ignorant persons are more likely to ignore the symptoms and avoid seeking medical care. From the viewpoint above one can infer that a country's development and wellbeing lies solely in the quality of education impacted to its citizenry. Therefore a holistic education that will touch the three domains of cognitive, affective and psychomotor is germane, as a neglect of any aspect will result in unprecedented social vices. For instance a high standard of quality education in any nation will give rise to improved changes in the nation's manpower and sustainability while an education system that permits character breakdown or moral decadence will breed touts, cultist and corrupt citizenry.

In the civilized western world, education of youth is considered a priority, because it assists in ensuring personal advancement and utilization of natural endowment facilities but Nigeria's image and reckoning, according to Adebiyi and Ganiyu (2016),seem to be nose diving in almost all facets of noble rating, whether from the perspective of its education, politics, economy, ethics and security. Genyi and Euginia (2013) on the other hand opined that peace and security of Nigeria has been seriously compromised, because of the inability of government and other relevant stakeholders to 
provide quality education to some sections of the country. There is no doubt that Nigeria as a nation is in a serious crisis arising from the insurgency which started some decades ago. Despite efforts to enhance peace and security from relevant agencies, it seems the trend of the menace is on the increase with new forms of vices coming up on daily basis.

Social vices are acts that contradict societal norms and values. Information Parlour ( $\left.{ }^{* * * * *}\right)$ in its facts sheet defined social vices as bad trait, unhealthy and negative behaviours that are against the morality of a society and frowned at by members of the society. It connotes all forms of immoral attitudes or deviant behaviour that are criminal or evil; they are acts that deviate from the acceptable standards of the society resulting from moral decadence. It includes cultism, drug abuse/alcoholism, indecent dressing, rape, examination malpractice, prostitution, kidnapping, ritual killing, robbery, cyber-crimes, gender violence, jungle justice etc. The fact that these nefarious activities are no longer restricted to out- of school youths makes it more worrisome. Social vices are now common among male and female within the school system most especially the undergraduates who are supposed to be the future leaders. There is escalation of moral decadence, corrupt practices, unabated terrorism and rising tide of social vices across age grades in Nigeria system and most especially among the undergraduates. In 2012, Nigeria was estimated to have lost $\$ 400$ billion to corruption since independence. In 2018 the country ranked $144^{\text {th }}$ among 180 countries, while the nation scored 26 points out of 100 on the 2019 corruption perception index reported by Transparency International. Even reports of social vices like rape, kidnapping, drug abuse, indecent dressing, killings, cultism on social media, radio, newspaper etc on daily basis is a clear indication that the nation has lost its pre - independence dignity among the comity of nations. No wonder American President Donald Trump refers to Nigeria as a chit hole while President Buhari called the youth who are supposed to be the strength base of the nation lazy youths.

Although social vices are not limited to Nigeria, they cut across the globe and not also limited to a particular age grade or colour. To corroborate the universality of social vices, Apase and Yawe (2019) asserted that Social vices are fast becoming national and global trends cutting across ethnic nationalities, races and even religious cleavages. However the rising tide among the youth mostly undergraduates and inability of stakeholders to checkmate the menace in Nigeria system makes it worrisome. In recent time, Nigeria has witnessed scores of deaths of innocent civilians and soldiers. The human carnage occasioned by Boko Haram, Fulani herdsmen clashes with sedentary farmers, kidnappings, targeted assassinations, arson and such other social vices are stretching the nation beyond its elastic limit. The saddest part of the story is that women who are life givers and who should be role models for the younger generation are also caught in the web of these nefarious activities as cases of women detonating bombs, involvement in bank robberies, acting as agents for sales of drugs and ammunitions have been reported in the past.

\section{Common Social Vices in Nigeria}

\subsection{Cultism}

There is no gainsaying the fact that activities of cultists have remained a serious clog in the wheel of progress of many institution of higher learning in Nigeria, with the trends finding its tentacles to other lower level of education at an alarming rate. Many untimely deaths of lecturers and students can be traced to clashes between one cult group and the other. Secret cults or societies according to Ogbonnaya (2012) are those organizations which completely conceal their rules, the names of their members, their signs, passwords from outsiders and the members take oath of secrecy and are often under the threat of severe punishment in the case of its violation. Onuegbu (2011) also observed that examples of secret cults abound in institution of learning at various levels and in wider society and their rituals may include swearing by a deity, human blood and other procedures experienced only by members whose major objectives could be to abolish convention, revive age long rivalry and other motive. Membership maybe out of one's volition (resulting from an intent of seeking recognition, poverty, fear of failure or rejection and depression) ignorance, peer pressure or coercion based on academic prowess or parental affluence and influence. In the past they perform their activities in clandestine manner but because of the level of decadence in the country they maim and kill their members, opponents and innocent people in broad day light without the perpetrators punished.

\subsection{Indecent Dressing}

In traditional African setting, goodness and reverence is synonymous to modesty. An adage says the way you dress determines the way you will be addressed. And the way one dresses can be used to measure the kind of home one comes from, unfortunately this much cherished culture has given way to indecent mode of dressing even in places of worship. This ugly trend of social vices is gradually becoming a norm as the society no longer sees anything bad in ladies wearing attires that revealed their body contours or boys putting trousers below their buttock (ass level). Girls wear dresses that will reveal their sensitive parts like thighs, cleavages. Tattered jeans, mini/ micro dresses and transparent materials are the order of the day. More embarrassing is that adult women (mothers and lecturers) who are also caught in the web, all in the name of following trending fashion or being social. This unabating vice has made many girls fall victim of rape, pre - marital or unguided sex, poor and low self - esteem leading many to depression and rejection in later life. Many ended up committing suicide when they are jilted by men who followed them initially to satisfy their lust. Concerted effort at reducing the ugly menace can be credited to Senator Eme, Ufot Ekaete; who in 2008 presented a bill titled 'An act to prohibit and punish public nudity, sexual Intimidation and related offences. 'The bill proposed three - months jail term for offenders. The bill drew some criticisms and controversy on ground that it will amount to violation of human rights. 


\subsection{Examination Malpractice}

Olu - Aderounmu cited by Akinleye an Makinde (2012) observed that the problem of examination malpractice has over the years grown giant satanic roots, spreading its tentacles to even the most revered of Nigeria's Institutions of learning and examining bodies like Nigerian Law School, JAMB, NECO, COREN,NIJ, WAEC just to mention a few. Examination malpractice according to him can be classified as examination leakages, cheating, impersonation, certificate forgery etc and that any candidate who indulges in any of them does so in order to have undue advantage over other candidates. Other forms of examination malpractice manifest are ghost centres, substitution of scripts, smuggling of foreign materials to the hall, copying, giraffing, writing on body parts, collusion with teachers and invigilators/supervisors etc. The bad trend is as old as the formal school system and has resulted into cancellation of centre results, individual students 'results, expulsion, loss of job or even life, yet the vice remained unabated as more digital methods keep rising on daily basis.

\subsection{Cyber Crime}

Without mincing words, cybercrime has become an increasingly large problem in our society most especially among undergraduates. It involves the use of the computer as an instrument to commit illegal activities like internet fraud, phone hacking, stealing information from bank etc. Panda Security (2018) defines it as a crime where a computer is the object of the crime or is used as tool to commit an offense. A cybercriminal may use a device to access a user's personal information, confidential business information, and government information or disable a device. It is also a cyber-crime to sell or elicit the above information online. Cyber-crime has created serious problem for internet users and may threaten the nation's security or financial health of the victim. No wonder IBM President and CEO Ginni Rometty described cybercrime as the greatest threat to every profession, every industry and every company in the world. In Nigeria, youths have taken cybercrime to another level like Yahoo+ a situation where local charms are used to hypnotise victims and human being used for rituals. Panda Security went further to state that types and methods used and difficulty levels vary depending on category. Some identified types which include cyber stalking, social engineering, potentially unwanted programs (PUPs), identity theft, Attacks, phishing, prohibited /illegal content, online scams and exploit kits

\subsection{Drug Abuse/Alcoholism}

These are vices that entail the use of chemical substance in a manner that differs from approved medical usage. Drug abuse has been described as the use of drugs to the extent that there is interference with the health and social function of an individual (Abudulahi, 2009). Drug abuse is caused by peer influence, faulty upbringing, Parental influence, unemployment, depression and means of gaining popularity. In recent time, drug abuse and alcoholism is almost turning a norm among undergraduates. The addition of hard drugs into coca cola is now in vogue. Common among such drugs are Tramador, Refnor, cocaine, marijuana, gegemu, madras, valium, tutolin and various types of alcoholic drinks. The consequences include loss of perception, loss of memory, and disrespect to constituted authority, madness, aggression and untimely death.

\subsection{Terrorism/Violence}

These terms have become a house hold words as they have promoted the breach of peace and security stemming from unlawful acts of destructions of lives and properties.

\subsection{Sexual Promiscuity/Prostitution}

This connotes illicit sexual practices with the opposite sex ranging from pre - marital sex, rape and all forms of sexual aggravation. Virginity which was held with high esteem in the traditional African setting is totally at vanishing point, those who maintained their virginity these days are seen as antisocial, many engage it for fun, money, to question the authority of parents, as mark of socialization, while some do it out of prolonged unemployment, and quest for higher grades. Some of the youth are ignorant of the consequences of these illicit sexual activities

\section{Causes / Factors Responsible for Social Vices among Undergraduates}

\subsection{Poverty}

So many families fall into the category of low socio-economic status in the country because their monthly income is not enough to feed the family. In a situation where only one person in family is working to feed the rest of the family members, there is no way such family can be alright economically. Majority of the so called undergraduates find themselves in this type of situation, many drop out of school because their parents are unable to pay school fees and so many were wide-opened to money making risks too early in life, the felt there is no need for them to go back to school since they are aware of the unemployment situation of the country. They thereby preferred to join their mates in vices like child trafficking, car snatching and even ritual killing

\subsection{Corruption}

Corruption is a form of dishonesty or criminal cases undertaken by a person or organisation entrusted with position of authority, to acquire illicit benefit or abuse power for ones' privilege gain. Corruption is caused generally by greed, lack of positive values, porous system, weak enforcement, societal pressure, poverty of the mind, Fagbadebo, 2017 stated in his work that Nigeria is a victim of high-level corruption, bad governance, political instability which has certainly 
led to social menace the country is facing today. So many undergraduates now want to be politicians in order to continue their bad behaviour that has led the country to a retarded state.

\subsection{Unemployment}

Lately, there have been a lot of discussions on the air pinpointing the causes of vices in Nigeria, unemployment is one of the issues discussed as one of the major causes of social vices. It is not out of place if unemployment is mentioned considering the population of on- the- street youths due to joblessness despite the facts that they are qualified and certified to work.

It is often said that the idle man mind is the devils' workshop. The undergraduates instead of focusing on their future by reading acidulously in order to graduate with good grades that will qualified them to work now prefer to go for cyber-crime because of their believe that those outside with good grades are unemployed. They therefore become readily available in the hands of the bad elements in the society and rotten politicians who are bent to distort the ruling government. Undergraduates now engage in crime like kidnapping, robbery, fraud, violent demonstration, dirty jobs that have posed a lot of injury to the society at large.

Furthermore, the activities of Nigerian youths have kept the foreign investors from coming in to the country to invest. Lack of unemployment has made some youth transferred their aggression to the public by vandalizing oil pipes, abduct foreigners demanding for huge ransom, the reactions that drastically affect the economic situation of the nation and the whole country insecure.

\subsection{Peer Pressure/ Peer Group}

This is the major cause of undergraduates' engagement in vices. Undergraduates (youths) spend much more of their time with friends at school or at home. These students can easily been influenced due to their weak nature and tender age, they tend to believe easily their age mates or a senior friend who happens to be their mentor or so called 'school father or mother'. Young ones have high level of curiosity to learn, to have fun and practice new things, since they are born with tabular rasa thus, making them smoke, drink and commit a lot of illicit acts agree with the proverb that says 'evil communicants corrupt good manners'. This shows the significance of friendship and how negatively/ positively they can influence themselves depending on what kind of relationship they had. An undergraduate tends to copy or imitate his or her colleagues so as not to be tagged as a Coward, Munmun, Novist, Journey Just Come, Amateur, unsocial and so on.

\subsection{Bad Behaviours from Teachers}

Education is an instrument that is used to improve an individual in order to become useful to the society. This form of Education can be gotten formally within the school environment where both curricular and extra-curricular activities take place. The Educators most especially teachers are meant to positively affect the life of students committed into their custody but now the reverse is the case. Teacher now help in examination malpractices by pretending as if he/she is not aware of student cheating in an Examination hall instead of reporting the case to disciplinary committee, they fail to discharge their duties promptly due to laziness and personal problems. Some even stoop so low to collect bribery from the student either by paying certain amount of money or sleeping with them of the victim are female. These attitudes do not encourage the undergraduate trust some so called teachers.

\subsection{Broken Homes}

Research had it that most undergraduates from broken homes involve themselves in social vices. Lack of care by the parents, inadequate monitoring and supervision, not given proper attention by the parent or guidance can make a student to engage in social vice. Undergraduates that would always have a permissive will at all time will definitely misbehave because he/she believes he/she can always get what he/she wanted at all cost. There had not been any time when both parents will take decision on the student. They move with wrong people without anyone querying their movements and no one care about their academic performance and progress. These categories of students are easily lured to cultism and deadly acts in a bid to seek for affection, advice, care, share emotions due to parental negligence. Some abandoned ladies ended up living a couple's life on campus in a bid to seek for refuge and someone who could help her emotions because the parents are too busy to help her. These ladies fall victim of rape, unwanted pregnancy, emotional trauma, psychological trauma that could make her lose attention on her study and probably stop schooling which will definitely cause her mates to leave her behind and go far ahead of her. Some separated parents have gradually destroyed their wards lives through negligence and too busy attitude towards their children some even leave their children care in the hands of housemaids and family member who in turns introduce these children into social vices.

\subsection{The Role of Women in Academia}

The place of women at home, in her place of work and even in the society in general cannot be undermined. They constitute slightly more than half of the total population. They are life giver and mothers to nurse and cater for husband, children and other people around them.

Women's pride lies in hidden and protected treasures, children's behaviour is believed to be influenced by the type of training and grooming received from home which is the first agent of socialization for the school to build upon. Women in academia are supposed to be role models for the students most especially girl to follow. They should also corroborate the effort of the school management towards organizing enlightenment programmes that will change the students' orientation and to boost their sense of self - esteem. 


\section{Conclusion}

From the submissions in this paper, it is not an exaggeration to conclude that the solutions to the rising tide in social vices among Nigerian undergraduates and youth generally lie on all stakeholders in the society; mostly women in academia have a vital role to play in their respective campuses. Women in academia should partner with their school management team to ensure that school curriculum is geared towards knowledge economy that would result in job and wealth creation. Courses like entrepreneur studies and moral education should be strengthened to enhance right attitude in the students. Adequate educational guidance and counselling should be sustained at all levels of education with more women participation as paraprofessionals. There should be proper monitoring of the students by both the parents and the school authority and also public punishment should be given to any student involving in any of the aforementioned vices.

\section{References}

i. Apase, J. A and Fawe, A.A. (2019). The Role of Education in Managing Social Vices and Youth restiveness. In Benue State University Journal of Educational Management Vol. I No. 1

ii. Adebiyi, M. E and Ganiyu, R. S (2016). Female Teachers' Disposition to value reorientation using ICT tools in primary schools in Oyo Town. In South West Journal of Women in Colleges of Education vol.3 9 - 18

iii. Apase, J. A \& Yawe A.A (2019). The role of Education in Managing Special Vice and Youth

iv. Restiveness. BSUJEM Vol.1No1 2019

v. Ariyo, B.(2017) Unemployment: Major Cause of Social Vices https://www.causesof socialvices.com>ty.

vi. Comfort, O. David, I. \& Moses, U. U. (2013). Addressing the insecurity challenges in Nigeria: the imperative of moral values and virtue ethics. In Global Journal of Human Social Sciences \& Political Science 13(2) 51 - 63

vii. Edogun, B. (2015). Importance of education in society. In the Nigerian Observer April 1

viii. Fagbadebo, O.M (2017). Corruption, Governance and Political Instability in Nigeria. https://www.semanticscholar.org>ty.

ix. Genyi, G. \& Euginia, M. (2013). Good governance: Antidote for peace and security in Nigeria. European Journal of Business and Social Scienes, 2(2), 56 - 65.

x. Okwori, A., \& Ede, S. (2012). Management issues in education. Makurdi. Aboki publishers. Wikipedia

xi. Imhonopi, D \& Urim, U.M (2012). The spectre of terrorism and Nigeria industrial>

xii. Panda Security 2018).Types of cybercrime. https://www.pandasecurity.com>ty... 